\title{
A point mutation in the albumin gene in a Chinese patient with familial dysalbuminemic hyperthyroxinemia
}

\author{
Kam-Tsun Tang ${ }^{1}$, Hong-Jyh Yang ${ }^{3}$, Kong-Bung Choo $^{2}$, Hong-Da Lin ${ }^{1}$, Shieh-Li Fang ${ }^{4}$ and Lewis E Braverman ${ }^{4}$ \\ ${ }^{1}$ Division of Endocrinology and Metabolism, ${ }^{2}$ Department of Medical Reasearch and Education, Veterans General Hospital-Taipei and National \\ Yang-Ming University, Taipei, Taiwan, ${ }^{3}$ Department of Medicine, Hsin Chu Hospital, Hsin Chu, Taiwan and ${ }^{4}$ Division of Genetics, Brigham and \\ Women's Hospital, Harvard Medical School, Boston, Massachusetts, USA
}

(Correspondence should be addressed to K-T Tang, Division of Endocrinology and Metabolism, Veterans General Hospital-Taipei, 201 Section 2 Shih-Pai Rd, Taipei, Taiwan, Republic of China; Email: kttang@vghtpe.gov.tw)

\begin{abstract}
Familial dysalbuminemic hyperthyroxinemia (FDH) is an autosomal dominant disorder characterized by euthyroid hyperthyroxinemia. However, FDH has not been reported in Chinese or African patients. Here, we report the first case of FDH in a Chinese patient. A 69-year-old Chinese man was found to have increased serum total $\mathrm{T}_{4}$ concentrations (198-242 nmol/l; normal range 58-148 nmol/l) and free $\mathrm{T}_{4}$ concentrations ( $>58 \mathrm{pmol} / \mathrm{l} ; \mathrm{T}_{4}$ analog method, normal range $9-28 \mathrm{pmol} / \mathrm{l}$ ). Serum total $\mathrm{T}_{3}$ and TSH concentrations were normal. The patient was misdiagnosed as hyperthyroid and was later suspected to have a TSH-producing tumor by the finding of a pituitary microadenoma, which was eventually proven to be a non-functional pituitary 'incidentaloma'. Electrophoretic analysis of the patient's serum proteins demonstrated enhanced albumin binding of $\left[{ }^{125} \mathrm{I}\right] \mathrm{T}_{4}$. Serum free $\mathrm{T}_{4}$ concentrations were normal (16-19 pmol/l, normal range 9-26 pmol/l) when a two-step method was used. Direct sequencing of the albumin gene showed a guanine to adenosine transition in the second nucleotide of codon 218, resulting in a substitution of histidine (CAC) for the normal arginine (CGC) in one of the two alleles in the patient. The point mutation was further confirmed by HphI digestion of exon 7 of the albumin gene. The patient's son was not affected. Our studies demonstrated that the point mutation of the albumin gene in a Chinese patient with FDH was similar to that found in western white families, but differed from that in a Japanese family in whom a guanine to cytosine transition at the same position was found.
\end{abstract}

European Journal of Endocrinology $141374-378$

\section{Introduction}

Familial dysalbuminemic hyperthyroxinemia (FDH) is an autosomal dominant syndrome characterized by an increased serum total thyroxine $\left(\mathrm{T}_{4}\right)\left(\mathrm{tT}_{4}\right)$, and free $\mathrm{T}_{4}\left(\mathrm{fT}_{4}\right)$ concentrations measured by the index and analog methods, whereas the serum $\mathrm{fT}_{4}$ determined by equilibrium dialysis or two-step methods are normal. The total tri-iodothyronine $\left(\mathrm{T}_{3}\right)\left(\mathrm{tT}_{3}\right)$ and thyroidstimulating hormone (TSH) concentrations, usually, are normal (1-6). These discrepancies are due to the presence of an abnormal serum albumin that exhibits enhanced binding of $\mathrm{T}_{4}$, and patients with FDH are clinically euthyroid (7-10). Although FDH has been widely reported in the medical literature and accounts for the most common cause of genetic euthyroid hyperthyroxinemia in western countries, particularly among hispanics of Puerto Rican origin (11-13), to our knowledge no case has been reported in individuals of Chinese or African origin. Recently, the molecular basis of FDH has been found to be a substitution of histidine (CAC) and proline (CCC) for arginine (CGC) in codon 218 of the albumin gene in unrelated western families and in a Japanese kindred, respectively (14-16). Recombinant human serum albumin with a substitution of $\mathrm{His}^{218}$ for $\mathrm{Arg}^{218}$ has been shown to have an increased affinity for $\mathrm{T}_{4}$, similar to the human serum albumin purified from the FDH patients, confirming that the substitution of $\mathrm{His}^{218}$ for $\mathrm{Arg}^{218}$ generates the phenotype of FDH (17-19). The $K_{\mathrm{a}}$ of FDH albuminPro ${ }^{218}$ for $\mathrm{T}_{4}$ in the Japanese kindred was approximately 80-fold that of albumin in normal individuals and the replacement of arginine by proline is believed to be responsible for this condition (16).

We now report the first case of FDH in a Chinese patient who had increased serum $\mathrm{tT}_{4}$ and $\mathrm{fT}_{4}$ concentrations (analog method) and normal serum TSH. The patient had been misdiagnosed as having thyrotoxicosis, and was suspected to have a TSH-producing tumor. Direct sequencing of the albumin gene revealed 
that the arginine (CGC) in codon 218 was replaced by histidine (CAC), which is similar to the genotype reported in western white individuals $(14,15)$, but differs from that reported in a Japanese family in whom the arginine (CGC) was replaced by proline (CCC) at the same position (16).

\section{Case report}

The patient was a Chinese male veteran, who was born in mainland China and moved to Taiwan during the Chinese civil war in 1949. He was accidentally found to have an increased serum $\mathrm{fT}_{4}$ concentration (analog method) in a routine examination in 1988 when he was 61 years old. The thyroid was normal and the patient had no signs of thyrotoxicosis or ophthalmopathy. The patient and his son were the only family members in Taiwan, and they had no significant medical problems. The family history of other members of the family was not available, because the patient's parents and other family members had passed away in mainland China many years previously.

Antithyroid drugs were prescribed for the suspected hyperthyroidism, but were discontinued by the patient after a few months of treatment. The patient complained of headache in 1992 and serum $\mathrm{tT}_{4}$ and $\mathrm{fT}_{4}$ were again found to be increased, but serum $\mathrm{tT}_{3}$ and TSH were normal. Computed tomography (CT) scan of the sella revealed a low-density, non-enhancing mass in the left pituitary fossa. A thyrotrophin-releasing hormone (TRH) test showed a normal TSH response to intravenous TRH administration, and other pituitary function tests were normal. The patient was diagnosed as having euthyroid hyperthyroxinemia with a nonfunctional small pituitary 'incidentoloma'. In 1995, serum $\mathrm{fT}_{4}$ was normal when a $\mathrm{fT}_{4}$ assay by the twostep method was used. The patient was referred to our laboratory for further evaluation, with the suspected diagnosis of FDH. The results of his thyroid function tests are shown in Table 1 . Serum $\mathrm{tT}_{4}$ concentrations were high, ranging from 198 to $242 \mathrm{nmol} / \mathrm{l}$, whereas serum $\mathrm{tT}_{3}$ and $\mathrm{TSH}$ concentrations were normal, ranging from 2.0 to $2.3 \mathrm{nmol} / \mathrm{l}$ and 1.64 to $2.42 \mathrm{mU} / \mathrm{l}$ respectively. Serum $\mathrm{fT}_{4}$ concentrations were
TBG

\section{Albumin}

\section{TTR}

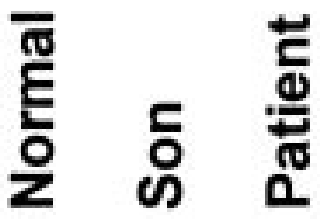

Figure 1 PAGE analysis of $\left[{ }^{125} \mathrm{I}\right] \mathrm{T}_{4}$ distribution among the serum thyroid hormone-binding proteins, thyroxine-binding globulin (TBG), albumin and transthyretin (TTR) of a normal volunteer, the patient, and his son.

strikingly increased ( $>58 \mathrm{pmol} / \mathrm{l})$ determined by a onestep analog method from 1988 to 1991 , but were normal (16-19 pmol/l) when measured by a two-step method after 1995. TSH receptor antibody, antimicrosomal and antithyroglobulin antibodies were not detected. Thyroxine-binding globulin (TBG) and thyroid iodine-131 uptake were normal. The serum TSH, $\mathrm{fT}_{4}, \mathrm{fT}_{3}, \mathrm{tT}_{4}$ and $\mathrm{tT}_{3}$ concentrations of the patient's son were within the normal ranges (data not shown) on two different occasions in 1996. The distribution of $\left[{ }^{125} \mathrm{I}\right] \mathrm{T}_{4}$ and $\left[{ }^{125} \mathrm{I}\right] \mathrm{T}_{3}$ among the serum thyroid hormone-binding proteins analyzed by $8 \%$ PAGE is shown in Fig. 1. There was no difference in the distribution of $\left.{ }^{[125} \mathrm{I}\right] \mathrm{T}_{4}$ in the TBG, albumin and transthyretin (TTR) zones in a normal volunteer and the patient's son. However, the distribution of $\left[{ }^{125} \mathrm{I}_{4}\right.$ was markedly increased in the albumin fraction in the patient's serum. There were no differences in the

Table 1 Results of thyroid function tests in the patient from 1988 to 1996.

\begin{tabular}{|c|c|c|c|c|c|c|c|c|c|c|}
\hline Date & $\begin{array}{c}\mathbf{t T}_{\mathbf{3}} \\
(\mathrm{nmol} / \mathrm{l})\end{array}$ & $\begin{array}{c}\mathbf{t T}_{\mathbf{4}} \\
(\mathrm{nmol} / \mathrm{l})\end{array}$ & $\begin{array}{c}\mathbf{f T}_{\mathbf{4}} \\
(\mathrm{pmol} / \mathrm{l})\end{array}$ & $\begin{array}{l}\text { TSH } \\
(\mathrm{mU} / \mathrm{l})\end{array}$ & $\begin{array}{l}\text { TBII } \\
(\%)\end{array}$ & AMA & ATA & $\begin{array}{l}\text { Albumin } \\
(\mathrm{g} / \mathrm{l})\end{array}$ & $\begin{array}{c}\text { TBG } \\
(\mathrm{nmol} / \mathrm{l})\end{array}$ & $\begin{array}{l}\text { Thyroid } \\
\text { 131 I uptake } \\
(\%)\end{array}$ \\
\hline Dec 1988 & & & $>58 \dagger$ & & & & & 44 & & \\
\hline Feb 1989 & 2.2 & 198 & $>58 \dagger$ & 2.05 & $<3$ & - & - & & & \\
\hline Mar 1992 & 2.1 & 205 & $>58 \dagger$ & 2.42 & $<3$ & & & 41 & & 35 \\
\hline Jun 1995 & 2.3 & 242 & $19 \ddagger$ & 1.64 & $<3$ & - & - & & & \\
\hline April 1996 & 2.0 & 218 & $16 \mp$ & 2.39 & & & & & 364 & \\
\hline Normal ranges & $1.3-2.5$ & $58-148$ & & $0.4-3.1$ & & & & $37-53$ & $172-463$ & $15-40$ \\
\hline
\end{tabular}

† One-step method; normal range 9-28 pmol//; † two-step method; normal range 9-26 pmol/l. TBII, TSH-binding inhibitory activity; normal range $<10 \%$. 
distribution of $\left[{ }^{125} \mathrm{I}\right] \mathrm{T}_{3}$ among the serum proteins in the patient, normal individuals, and the patient's son (data not shown). DNA fragments containing all exons of the albumin gene obtained from the patient, the patient's son and a normal volunteer after PCR amplification were subjected to direct sequencing. The results revealed a guanosine to adenosine transition in the second nucleotide of codon 218 in exon 7 of the patient (Fig. 2). This transition results in the replacement of arginine by histidine. Guanosine was also present at the same position, suggesting that the patient was heterozygous. No mutations were seen in the patient's son and the sequence was identical to that in normal individuals. DNA sequences of all other exons from the patient's albumin gene were identical to the albumin gene reported previously (20). The PCR products of exon 7 containing DNA fragments (355 bp) were digested by HphI. Partial digestion was seen in the patient's DNA fragments, which formed two bands (Fig. 3). The DNA fragment with $355 \mathrm{bp}$ represented the undigested portion, which carried the normal DNA sequence. The thick band seen at position about $180 \mathrm{bp}$ represented the digestion of the mutant exon 7 into an

FDH codon 218 $\operatorname{Arg}(C G C) \rightarrow H$ is $(C A C)$
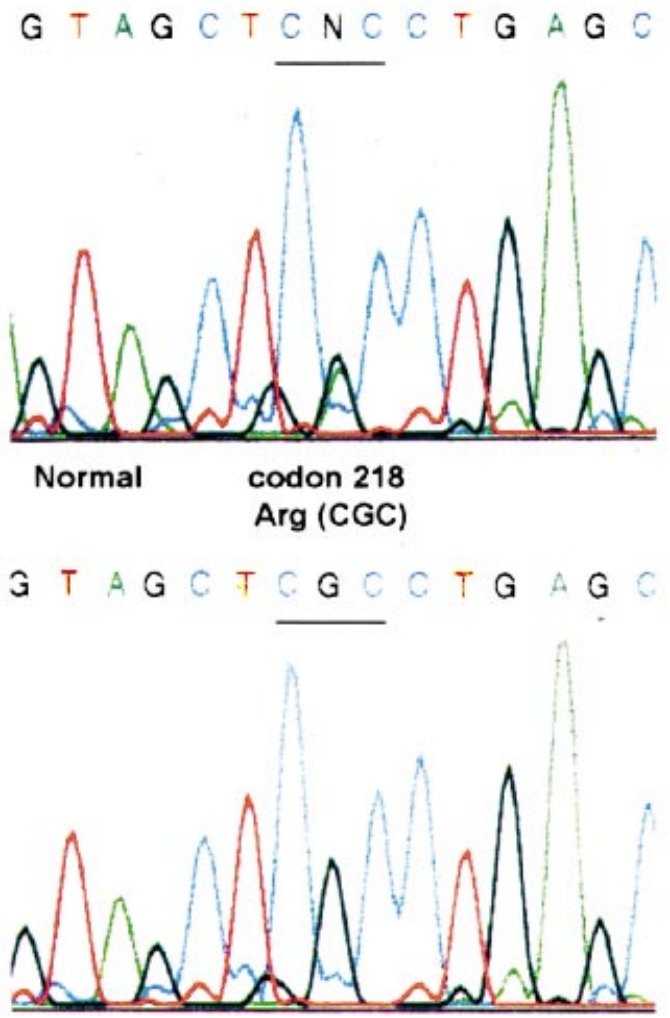

Figure 2 DNA sequences of exon 7 of the albumin gene in the patient (upper panel) and a normal volunteer (lower panel).
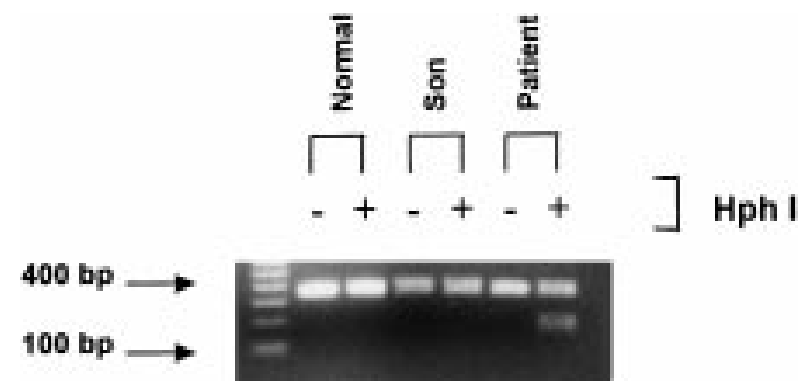

Figure 3 PCR products of exon 7 of the albumin gene in the patient, the patient's son and a normal volunteer. + , with Hphl digestion; -, without Hphl digestion.

unsolved doublet containing fragments $172 \mathrm{bp}$ and $182 \mathrm{bp}$. The DNA fragments of the patient's son and the normal volunteer were not digested by HphI. The results were compatible with the DNA sequencing, suggesting a guanine to adenosine transition in the second nucleotide of codon 218 of the albumin gene in one of the patient's two alleles.

\section{Methods}

Serum $\mathrm{tT}_{4}$ was measured by GammaCoat $\left[{ }^{125} \mathrm{I}_{\mathrm{tT}}\right.$ radioimmunoassay kit (Dade Baxter Travenol Diagnostic Inc., Cambridge, MA, USA). Serum $\mathrm{fT}_{4}$ concentrations were measured by a one-step analog method by GammaCoat $\left[{ }^{125} \mathrm{I}\right] \mathrm{fT}_{4}$ radioimmunoassay kit (Dade Baxter Travenol Diagnostic Inc.) before 1995 and by a two-step method by GammaCoat $\mathrm{fT}_{4}$ (two-step) $\left[{ }^{125} \mathrm{I}\right]$ RIA kit (Incstar Corporation, Stillwater, MN, USA) after 1995. Serum $\mathrm{tT}_{3}$ was measured by SPAC T3 RIA kit (Daichi, Tokyo, Japan). Serum TSH was determined by Clinical Assay GammaCoat hTSH [ $\left.{ }^{125} \mathrm{I}\right]$ IRMA kit (Incstar Corporation). Antimicrosomal (AMA) and antithyroglobulin antibodies (ATA) were measured by hemagglutination and TBG by a time-resolved fluoroimmunoassay method (Delfia, Wallac Oy, Turku, Finland). The distribution of tracer concentrations of $\left[{ }^{125} \mathrm{I}\right] \mathrm{T}_{4}$ and $\left[{ }^{125} \mathrm{I}\right] \mathrm{T}_{3}$ among serum proteins was measured by $8 \%$ PAGE in phosphate buffer ( $\mathrm{pH} 9.0$ ) as described previously $(3,21)$. Genomic DNA was isolated from peripheral blood using the Puregene DNA isolation kit (Gentra System, Inc., MN, USA) (22). DNA fragments containing each exon of the albumin gene were generated by PCR (Gene Amp PCR System 2400, Perkin-Elmer Co., Norwalk, CT, USA) using primers synthesized according to genomic sequences as reported previously $(15,16,20)$. The purified PCR products of all exons were sequenced directly using the same primers as PCR with ABI Prism dye terminator cycle sequencing ready reaction kits (Perkin-Elmer Co.) and sequenced on a Perkin-Elmer DNA Sequencer Model 377. The amplified DNA fragments containing exon 7 of the patient, the patient's son and normal volunteers were digested by HphI (New England Biolabs, 
Beverly, MA, USA) or water (for negative control) and subjected to electrophoresis on a 3\% agarose gel (15).

\section{Discussion}

Measuring $\mathrm{fT}_{4}$, instead of $\mathrm{tT}_{4}$ has the additional advantage of differentiating patients with thyrotoxicosis from a substantial proportion of patients with euthyroid hyperthyroxinemia caused by increased thyroid hormone binding to serum proteins. However, in the one-step analog $\mathrm{fT}_{4}$ assay, the abnormal albumin in patients with FDH has an increased binding affinity for the $\left[{ }^{125} \mathrm{I}\right] \mathrm{T}_{4}$ analogs, which decreases the binding of the analogs to the antibodies, resulting in overestimation of the $\mathrm{fT}_{4}$ concentration (4-6). Accordingly, patients with FDH may be misdiagnosed as having hyperthyroidism and be inappropriately treated, as was the case with this patient (1-7). Furthermore, they may also be misdiagnosed as having inappropriate TSH secretion, as the serum TSH is normal $(23,24)$. In our patient, the finding of a pituitary microadenoma by CT scan, associated with the increased serum $\mathrm{tT}_{4}$ and $\mathrm{fT}_{4}$ but normal TSH, suggested the possibility of a TSH-producing tumor. However, pituitary enlargement is a common disorder and pituitary 'incidentalomas' are present in $10-20 \%$ of the population according to autopsy reports and careful imaging studies $(25,26)$. The normal serum $\mathrm{T}_{3}$ concentration and TRH test in this patient were particularly useful in excluding the possibility of a TSH-producing tumor. Although FDH had not previously been reported in Chinese, the finding of a normal serum $\mathrm{fT}_{4}$ concentration determined by a two-step method in the later tests raised the distinct possibility of FDH in this patient. The diagnosis was eventually confirmed by demonstrating the point mutation in exon 7 of the albumin gene as described in western white populations $(14,15)$, although this differs from the mutation reported in a Japanese family (16). The guanine to adenosine transition in the second nucleotide of codon 218 of the albumin gene, resulting in the replacement of the normal arginine by histidine in one of the two alleles has been confirmed to be responsible for the phenotype of FDH in western white families $(18,19)$. The guanine to cytosine transition in the same position, causing the replacement of the arginine by proline in the Japanese kindred, produced a distinct phenotype of FDH that displays greater serum $\mathrm{tT}_{4}, \mathrm{tT}_{3}$ and $\mathrm{rT}_{3}$ concentrations (16). The findings suggest that codon 218 located in subdomain $2 \mathrm{~A}$ of human serum albumin has an important role in the high binding affinity of $\mathrm{T}_{4}(27)$.

In human serum albumin, the guanidino group of arginine at codon 218 is involved in an unfavorable binding interaction with the amino group of $\mathrm{T}_{4}$ (19). As neither histidine nor proline has the guanidino group, the FDH His ${ }^{218}$-albumin or Pro ${ }^{218}$-albumin produces a more favorable binding interaction with $\mathrm{T}_{4}$. Probably, the FDH Pro ${ }^{218}$-albumin may induce conformational changes in the $\mathrm{T}_{4}$-binding site that may have a higheraffinity $\mathrm{T}_{4}$ binding than the normal albumin and FDH His $^{281}$-albumin (16).

In conclusion, FDH is present in Chinese, and a mutation of the serum albumin gene that is the same as that described in western white populations, but which differs from the mutation reported in a Japanese family. DNA analysis is a rapid and simple method with which to confirm the diagnosis and etiology of $\mathrm{FDH}$, and is particularly useful in small families for whom there is no detailed pedigree or FDH history.

\section{Acknowledgements}

We thank Dr T S Jap for referring to us this unusual case. This work was supported by National Science Council (NSC87-2314-B-038), Taiwan; Veterans General Hospital-Taipei (1997-42), Taiwan and NIH (DK18919), Bethesda, MD, USA.

Presented in part at the 79th Annual Meeting of The Endocrine Society, June 11-14 1997, in Minneapolis, MN, USA.

\section{Reference}

1 Hennemann G, Docter R, Krenning EP, Bos G, Otten M \& Visser TJ. Raised total thyroxine and free thyroxine index but normal free thyroxine. A serum abnormality due to inherited increased affinity of iodothyronines for serum binding protein. Lancet 1979 1 639-642.

2 Lee WNP, Golden MP, Van Herle AJ, Lippe BM \& Kaplan SA. Inherited abnormal thyroid hormone-binding protein causing selective increase of total serum thyroxine. Journal of Clinical Endocrinology and Metabolism 197949 292-299.

3 Ruiz M. Rajatanavin R. Young RA. Taylor C. Brown R, Braverman LE et al. Familial dysalbuminemic hyperthyroxinemia: a syndrome that can be confused with thyrotoxicosis. New England Journal of Medicine 1982306 635-639.

4 Rajatanavin MD, Fournier LAA, Decosimo DMD, Abreau CBS \& Braverman LE. Elevated serum free thyroxine by thyroxine analog radioimmunoassays in euthyroid patients with familial dysalbuminemic hyperthyroxinemia. Annals of Internal Medicine 198297 865-866.

5 Stockigt JR, Stevens V, White EL \& Barlow JW. 'Unbound Analog' radioimmunoassays for free thyroxine measure the albumin bound hormone fraction. Clinical Chemistry 198329 1408-1410.

6 Nayer P, Malvaux P \& Beckers C. Familial dysalbuminemic hyperthyroxinemia (FDH): inadequacy of the 'analog' methods for assaying free-T4 levels. European Journal of Nuclear Medicine 1984 $9284-285$.

7 Stockigt JR, Topliss DJ, Barlow JW, White EL, Hurley DM \& Taft P. Familial euthyroid thyroxine excess: an appropriate response to abnormal thyroxine binding associated with albumin. Journal of Clinical Endocrinology and Metabolism 198153 353-359.

8 Docter R, Bos G, Krenning EP, Fekkes D, Visser TJ \& Hennemann G. Inherited thyroxine excess: a serum abnormality due to an increased affinity for modified albumin. Clinical Endocrinology $198115363-371$.

9 Lalloz MRA, Byfield PGH \& Himsworth RL. Hyperthyroxinaemia: abnormal binding of $\mathrm{T} 4$ by an inherited albumin variant. Clinical Endocrinology $19831811-24$.

10 Yabu Y, Amir SM, Ruiz M, Braverman LE \& Ingbar SH. Heterogeneity of thyroxine binding by serum albumins in normal subjects and patients with familial dysalbuminemic 
hyperthyroxinemia. Journal of Clinical Endocrinology and Metabolism $198560451-459$.

11 Weiss RE, Sunthornthevarakul T, Angkeow P, Marcus-Bagley D, Cox N. Alper CA et al. Linkage of familial dysalbuminemic hyperthyroxinemia to the albumin gene in a large Amish kindred. Journal of Clinical Endocrinology and Metabolism 1995 $80116-121$.

12 Arevalo G. Prevalence of familial dysalbuminemic hyperthyroxinemia in serum samples received for thyroid testing. Clinical Chemistry 199137 1430-1431.

13 DeCosimo DR, Fang SL \& Braverman LE. Prevalence of familial dysalbuminemic hyperthyroxinemia in Hispanics. Annals of Internal Medicine 1987107 780-781.

14 Sunthornthepvarakul T, Angkeow P, Weiss RE, Hayashi Y \& Refetoff S. An identical missense mutation in the albumin gene results in familial dysalbuminemic hyperthyroxinemia in 8 unrelated families. Biochemical and Biophysical Research Communications 1994202 781-787.

15 Petersen CE, Scottolini AG, Cody LR, Mandel M, Reimer N \& Bhagavan NV. A point mutation in the human serum albumin gene results in familial dysalbuminaemic hyperthyroxinemia. Journal of Medical Genetics 199431 355-359.

16 Wada N, Chiba H, Shimizu C, Kijima H, Kubo M \& Koike T. A novel missense mutation in codon 218 of the albumin gene in a distinct phenotype of familial dysalbuminemic hyperthyroxinemia in a Japanese kindred. Journal of Clinical Endocrinology and Metabolism 199782 3246-3250.

17 Rushbrook JI, Becker E, Schussler GC \& Divino CM. Identification of a serum albumin species associated with familial dysalbuminemic hyperthyroxinemia. Journal of Clinical Endocrinology and Metabolism $199580461-467$.
18 Petersen CE, Ha CE, Mandel M \& Bhagavan NV. Expression of a human serum albumin variant with high affinity for thyroxine. Biochemical and Biophysical Research Communications 1995214 1121-1129.

19 Petersen CE, Ha CE, Jameson DM \& Bhagavant NV. Mutations in a specific human serum albumin thyroxine binding site define the structure basis of familial dysalbuminemic hyperthyroxinemia. Journal of Biological Chemistry 1996271 19110-19117.

20 Minghetti PP, Ruffner DE, Kuang WJ, Dennison OE, Hawkins JW, Beattie WG et al. Molecular structure of the human albumin gene is revealed by nucleotide sequence within q11-22 of chromosome 4. Journal of Biological Chemistry 1986261 6747-6757.

21 Davis PJ, Spaulding SW \& Gregerman RI. The three thyroxinebinding proteins in rat serum: binding capacities and effects of binding inhibitors. Endocrinology 197087 978-986.

22 Buffone GJ. Isolation of DNA from biological specimens without extraction with phenol. Clinical Chemistry 198531 164-165.

23 Smallridge RC. Thyrotropin-secreting pituitary tumors. Endocrinology and Metabolism Clinics of North America 198716 765-792.

24 Refetoff S, Weiss RE \& Usala SJ. The syndromes of resistance to thyroid hormone. Endocrine Review 199314 348-399.

25 Molitch ME \& Russell EJ. The pituitary 'incidentaloma.' Annals of Internal Medicine 1990112 925-931.

26 Molitch ME. Pituitary incidentalomas. Endocrinology and Metabolism Clinics of North America 199726 725-740.

27 Xiao MH \& Carter DC. Atomic structure and chemistry of human serum albumin. Nature 1992358 209-215.

Received 19 April 1999

Accepted 3 June 1999 